DOI: 10.19195/0137-1150.163.47

\author{
ANNA MARIA SKIBSKA \\ Uniwersytet im. Adama Mickiewicza w Poznaniu, Polska \\ annaskibska@amu.edu.pl
}

\title{
Dyskretna apologia starości w twórczości Milana Kundery
}

Les testaments trahis (1993), czyli Zdradzone testamenty stanowić będą w moim eseju, a ściślej: w jego pierwszej części, swego rodzaju archiwum, w którego zakurzonych z definicji pasażach przechadza się starość właśnie ${ }^{1}$. Pojmować ją pragnę jako metaforyczną inkarnację wielkiego literackiego kanonu, uosobienie tradycji, podszytej także tymi ,innymi tradycjami”, o których pisze John Ashbery $^{2}$. Zanim jednak nastąpi właściwa opowieść, należy dokonać introdukcji, wezwać na scenę protagonistów, bez których dzieje literatury (bądź szerzej: kultury) nie byłyby zwyczajnie możliwe. W passusie zatytułowanym Studnia przeszłości Milan Kundera, na mocy otwartej współpracy z Tomaszem Mannem, odwołuje się do dwóch żywiołów, naśladownictwa oraz kontynuacji, które w odniesieniu do literatury (powieści europejskiej) traktuje jako założycielskie. Pod nieobecność owych żywiołów, odpowiedzialnych za wszelkie gesty amplifikacji, śledzona w Zdradzonych testamentach historia powieści, ustawiona w jawnej kontradykcji wobec nieludzkiej Historii ludzkości, nie miałaby racji bytu. Implikujące kontynuację naśladownictwo (co do którego Kundera nie omieszka podkreślić, że „nie oznacza braku autentyczności, gdyż jednostka nie może nie naśladować tego, co już się zdarzyło; jakkolwiek poważna, jest ona tylko nowym wcieleniem; jakkolwiek prawdziwa, jest ona tylko wypadkową namów i nakazów

${ }^{1}$ Niemal w całym eseju korzystam z odwołań do francuskojęzycznych tekstów Milana Kundery, co tłumaczy decyzję korzystania z przekładów stylistycznie jednorodnych, gdyż pochodzących od Marka Bieńczyka.

2 Skojarzenie z „innymi tradycjami”, którym hołduje amerykański poeta, zawdzięczam Barthes'owskiej frazie ,ariergarda awangardy”, oznaczającej intrygujące inwestowanie w przeszłość literatury w celu nadania własnemu pisaniu odcienia nowości. Frazę tę przywołuje Grzegorz Jankowicz we Wszystkich konsekwencjach niedoskonatości, stanowiących wprowadzenie do: J. Ashbery, Inne tradycje, przeł. J. Fiedorczuk et al., przedmowa G. Jankowicz, Kraków 2008, s. 13. 
bijących ze studni przeszłości"3) determinuje niepochwytną istotę sztuki pisania, która sprowadza się do pojmowanej ejdetycznie trangresji, będącej zaś wyrazem twórczej wolności człowieka. Aby zrozumieć Kunderowską walkę o historię powieści, warto z cierpliwym namysłem pochylić się nad poniższym fragmentem, zainicjowanym poprzez intrygującą pytajność:

Osobisty charakter historii powieści? Czy po to, by na przestrzeni wieków powstała jedna całość, nie powinien łączyć tej historii jeden wspólny, stały, z konieczności zatem bezoosobowy sens? Nie. Sądzę, że nawet ten wspólny sens pozostaje zawsze osobisty, ludzki, gdyż podczas biegu dziejów koncept tej czy innej sztuki (czym jest powieść?) oraz sens jej ewolucji (skąd przychodzi i dokąd zmierza?) są nieustannie definiowane, definiowane wciąż na nowo przez każdego artystę, przez każde nowe dzieło. Sensem historii powieści jest poszukiwanie tego sensu, jego wieczne stwarzanie, stwarzanie na nowo, które obejmuje zawsze, ruchem wstecz, całą przeszłość powieści ${ }^{4}$.

Warunkiem stwarzania jest zatem poszukiwanie oznaczające za każdym razem zanurzanie się w studni przeszłości, obcowanie z literaturą, która ponad wszelką wątpliwość należy do domeny starości, przeze mnie w tym właśnie miejscu postrzeganej jako konstytutywny dla twórczego działania na słowach gest afirmacji. Zgoda na starość — to raison d'être literatury, w Kunderowskim „ruchu wstecz” wędrującej ku przygodzie, jaką jest inspiracja umożliwiająca rozkosz przekraczania granic „owej dziwnej — jak utrzymuje Jacques Derrida — instytucji”" Rozmyślanie nad nią w kontekście starości, którą nietrudno utożsamić z przeszłością przedromantycznych paradygmatów narracyjnych, zawiera w sobie kardynalne staranie o utrzymanie przy życiu „wzgardzonego dziedzictwa Cervantesa", w którego świetle ustanawiają się wszelkie następne formy powieściowe, konstruując nieskończoną konstelację intertekstualnych odniesieńn ${ }^{6}$.

${ }^{3}$ M. Kundera, Zdradzone testamenty. Esej, z francuskiego przeł. M. Bieńczyk, Warszawa 1996, s. 17.

${ }^{4}$ Ibidem, s. 20-21. Przywołany cytat wyraziście potwierdza przynależność Kundery do obozu zwolenników Nietzscheańskiej idei wiecznego powrotu, polegającej na stałym i ożywczym przepracowywaniu zastanych tradycji, konwencji, stylów oraz form. Powracanie do „korzeni” determinuje wszak historię oraz rozwój powieściowości.

5 „Dziwność” literatury, o jakiej pisze Derrida, wiąże się z jej ejdetyczną apofatycznością, uniemożliwiającą klarowne zdefiniowanie tego twórczego żywiołu, który każdorazowo jawi się „fascynującym zdarzeniem jednostkowości”, fascynującym przede wszystkim z powodu oporu sygnatury wobec interpretacji. Wszystko to sprawia, że literatura „wytwarza zdarzenia, których 'realność' lub trwanie nigdy nie jest pewne, lecz które z tego właśnie względu bardziej prowokują do myślenia, jeśli cokolwiek to jeszcze znaczy. [...] literatura nie posiada ani ustalonej istoty, ani też istnienia. Sprawia ona, że nigdy nie dostaniesz się do samej literatury, lecz tylko do pewnych [jej] właściwości, do tych mianowicie, które dzieło literackie podziela lub zapożycza, a które możesz znaleźć w innych tekstach". Ta dziwna instytucja zwana literatura. Z Jacques'em Derrida rozmawia Derek Attridge, przeł. M.P. Markowski, [w:] Dekonstrukcja w badaniach literackich, red. R. Nycz, Gdańsk 2000, s. 222-223.

${ }^{6}$ Podana w cudzysłowie fraza pochodzi ze Sztuki powieści - stanowi tytuł pierwszej części eseju Kundery, który jest swego rodzaju hołdem składanym powieści wieloznacznej, zapatrzonej w rozległe horyzonty, wolnej od demonicznej Historii i totalitarnej ideologii. Kundera pisze: 
Kundera, będąc niezwykle konsekwentnym orędownikiem owego dziedzictwa, co dostrzec łatwo w jego wielu złożonych komentarzach pisanych pod adresem prywatnego kanonu, dzieli się ze swoimi czytelnikami pesymistyczną w swym wygłosie prognozą, z której wynika, że:

Duch powieści jest duchem ciągłości: każde dzieło stanowi odpowiedź na dzieła poprzednie, każde dzieło zawiera całe dotychczasowe doświadczenie powieści. Ale duch naszych czasów wpatruje się w to, co jest teraz, w aktualność do tego stopnia zaborczą i ekspansywną, że wypiera ona z naszego pola widzenia przeszłość i sprowadza czas do jednej, trwającej właśnie chwili. Powieść, zamknięta w tym systemie, nie jest już dziełem (rzeczą, której przeznaczeniem jest trwanie i łączenie przeszłości z przyszłością), lecz wydarzeniem aktualnym takim jak wszystkie inne; jest gestem bez jutra ${ }^{7}$.

Wyrazistym i pięknym zaprzeczeniem owego „gestu bez jutra” jest ruch narracyjnej amplifikacji, z którego wyrasta czy też „wynurza się” (jak chce Kundera) słynna bohaterka Nieśmiertelności, Agnes, cudowna rzeczniczka elipsy, inspirująca do pisarskiego działania François Ricarda oraz Marka Bieńczyka ${ }^{8}$. Agnes na podobieństwo Ariadny jawi się depozytariuszką nici, za sprawą której z Kunderowskiego labiryntu powieściowego wysnuwają się eseistyczne rozwinięcia na temat tej właśnie postaci, z przenikliwym wdziękiem tworzone przez przywołanych autorów. W samym zdarzeniu inspiracji, które tutaj mogę tylko zasygnalizować, mieści się ów „duch ciągłości” — o jego wszak losy obawia się,

„Duch powieści jest duchem złożoności. Każda powieść mówi czytelnikowi: »rzeczy są bardziej złożone, niż myślisz«. Tak brzmi wieczna prawda powieści, lecz cichnie ona w tumulcie łatwych i prędkich odpowiedzi, poprzedzających i unicestwiających pytanie”. M. Kundera, Sztuka powieści. Esej, wyd. drugie zmienione, z francuskiego przeł. M. Bieńczyk, Warszawa 2004, s. 23.

7 Ibidem, s. 23-24.

${ }^{8}$ Elipsa pozostaje w czytelnej korespondencji wobec doświadczenia wygnania, permanentnie rekonstruowanego we francuskojęzycznych (i nie tylko) tekstach Kundery; jego nosicielami są bohaterowie Śmiesznych miłości (dr Havel i Eduard), Żartu (Ludwik), Życie jest gdzie indziej (czterdziestoletni mężczyzna), Walca pożegnalnego (Jakub), Księgi śmiechu i zapomnienia (Tamina i Jan), Nieznośnej lekkości bytu (Tomasz i Sabina), Powolności (kawaler i pani de T.), Tożsamości (Chantal), Niewiedzy (Józef). „In the existence of each of them we meet again, in various forms and tonalities, the same anti-Hegelian novelistic model, or the same antimodel: that of the deserter, the person who chooses not to confront the world anymore, to abandon the fight, to disappear. That disappearance [...] can be achieved in many ways. But each time it lays out the same motifs of bifurcation, of 'disengagement,' of a progressive or sudden splitting by which consciousness loses its interest in what had hitherto held sway over it, withdraws the credit it had granted from the values, goals, and desires that had hitherto been guiding it, and takes off along a crossroad". F. Ricard, Agnès's Final Afternoon. An essay on the work of Milan Kundera, przeł. A. Asher, London 2003, s. 17. „Agnès [...] nie chce siebie przekroczyć, nie chce posiąść świata i nie chce być panią siebie samej, chce być obecna w nieobecności, wykluczyć siebie nie tylko ze świata, lecz z własnego losu przede wszystkim: poszukuje odludzia, miejsca na uboczu, gdzie nie chce z nikim ani z niczym walczyć, lecz znikać i zanikać, zacierać siebie samą; nie chce wynosić siebie wyżej, ponad innych, osiągać coś, czego inni nie mają, lecz zabierać siebie z samej siebie, we własnym istnieniu znajdować szczęśliwą nie-siebie; nie 'być sobą', jak wszyscy dookoła pragną w najbardziej powszechnym i najwznioślejszym banale ('najważniejsze to pozostać sobą'), lecz właśnie sobą nie być'. M. Bieńczyk, Książka twarzy, Warszawa 2012, s. 412-413. 
może nie do końca słusznie, Kundera. Nadmienić przy tej okazji warto o podobnych odnośnie kanonu przeświadczeniach od lat filtrowanych przez słynną strategię misreading, która w wersji Harolda Blooma układa się w wielowiekową elegię intonowaną przez należących do różnych czasów i epok spadkobierców Dantego, Szekspira, Miltona ${ }^{9}$. Elegia ta nieodmiennie demonstruje, w oczach twórcy lęku przed wpływem, metaleptyczny w swoim temporalnym aspekcie paradoks polegający na nieustępliwym triumfie wielkich starców literatury, których dzieła po współczesność wykreślają mapy, po jakich stale się poruszamy. W pewnym sensie przegrani (spóźnieni), gdyż legendarni prekursorzy byli wszędzie tam przed na$\mathrm{mi}^{10}$. Sądzę, iż Kundera, raczej powierzchownie i niesprawiedliwie przez Blooma odczytywany, zgodziłby się z tym rozpoznaniem, zwłaszcza w odniesieniu do preferowanej przez niego kategorii komizmu, utożsamianej tyleż ze śmiechem, zdarzeniem czystej radości, opisywanej na przykładzie sędziwego Janáčka czy Picassa, co z dojrzałością dystansu, pozwalającego dostrzec śmieszność ludzkiej ezgystencji, odkrywanej pod nieobecność idei, zarówno wielkich, jak i małych (casus współczesnej nieczytelności Diderota!) ${ }^{11}$.

Problematyka gestu zdolnego do zaprojektowania literackiej przyszłości wpisuje się, co istotne z perspektywy starości, w serię tematów, sytuacji, mo-

${ }^{9}$ Bloomowska strategia misreading zakłada „konieczność” twórczego odczytania dzieł prekursorów, które jest zawsze błędnym odczytaniem, umożliwiającym wyzwolenie się adeptów sztuki słowa spod przemożnego wpływu mistrzów, którym nieodmiennie patronuje Szekspir: „lęk przed wpływem — czytamy w Lęku przed kontaminacja — leży u agonistycznych źródeł każdej twórczości literackiej”. H. Bloom, Lęk przed wptywem. Teoria poezji, przeł. A. Bielik-Robson, M. Szuster, Kraków 2002, s. 22.

${ }^{10} \mathrm{~W}$ elegijnej pieśni na temat wielkiego kanonu literackiego jego centralne miejsce u Blooma zajmować (podążającego za Emersonem) będzie zawsze Szekspir: „In any case, we cannot rid ourselves of Shakespeare, or of the Canon that he centers. Shakepseare, as we like to forget, largely invented us; if you add the Rest of the Canon, then Shakesperae and the Canon wholly invented us". H. Bloom, The Western Canon. The Books and School of the Ages, Papermac, Londyn 1995, s. 40 .

${ }^{11}$ We wstępie do dedykowanych Kunderze esejów Bloom, ograniczając się do krótkiego omówienia Nieznośnej lekkości bytu, ujawnia nie tyle własny brak zachwytu nad komentowanym pisarstwem, ile raczej brak orientacji w jego tematycznym zakresie i formalnych aspektach. H. Bloom, Introduction, [w:] Milan Kundera, Philadelphia 2003, s. 4-12.

Nieczytelność Diderota wiąże się z artystyczną wolnością powieści spod jego znaku: „Przypominam sobie pierwszą lekturę Kubusia Fatalisty: zachwycony jego odważnie różnorodnym bogactwem, gdzie refleksja styka się z anegdotą, gdzie jedna opowieść kryje w sobie drugą, zachwycony wolnością kompozycji, która kpi sobie z zasady jedności akcji, zastanawiałem się: czy ten wspaniały nieporządek wynika z cudownej konstrukcji, kunsztownie wyrachowanej, czy też wynika z euforii czystej improwizacji? Bez najmniejszej wątpliwości przeważa tu improwizacja; jednak pytanie, które spontanicznie sobie postawiłem, uzmysłowiło mi, że w tej upojnej improwizacji kryje się możliwość złożonej, bogatej kompozycji, która zarazem jest doskonale wyrachowana, wymierzona i przemyślana, jak przemyślaną musiała być najbardziej nawet wybujała architektoniczna fantazja katedry. [...] W przeciwieństwie do szachisty artysta wymyśla reguły sam dla siebie; improwizując bez reguł nie jest zatem bardziej wolny, niż wymyślając własny system regul”. M. Kundera, Zdradzone testamenty..., s. 23. 
tywów, pojedynczych słów nawet, z których powodu wielbiciel Rabelais'ego i Flauberta konstruuje swoje wariantywne narracje. Seria ta stanowi fundament pod permanentną opowieść o zadaniu zwanym życiem, więcej nawet: warto rozpoznać w niej swego rodzaju „źródło”, z którego mglistej otchłani wyłaniają się bohaterowie Kundery, aby w tej samej mgle, na podobieństwo Majakowskiego ze Zdradzonych testamentów (ZT, 214), na zawsze zniknąć. Długowieczność owych tematów mierzyć można właśnie kryterium starości: są one sędziwe niczym literatura, nowe są tylko opowieści tworzone z ich przyczyny. Ich zadaniem, zbieżnym z ciągłym przepracowywaniem kilku sytuacji egzystencjalnych, jest twórcza proliferacja sensów wystawiających się na samoutratę, na wygnanie, pieczołowiecie rekonstruowane ad vocem Agnes. Sztuka powieściowa przeistacza się w zdarzenie chiazmu, w którego centrum krzyżują się odwieczne problemy natury ludzkiej oraz wciąż z ich powodu ponawiane eksplikacje, sugerujące $\mathrm{z}$ jednej strony niemożność epistemologicznego pochwycenia tychże problemów, z drugiej — uwypuklające skandal czasowości odpowiedzialny za powszechną niecierpliwość stymulującą iluzoryczny pęd ku poznaniu, w czasie którego niepostrzeżenie traci się własne, jednostkowe bycie. U Kundery docenić je potrafi tylko ktoś, kto jak Tamina z Księgi śmiechu i zapomnienia, znalazł się poza owym niecierpliwym pędem ku nieśmiertelności: w jednej ze scen zamykających oniryczną przygodę na wyspie dzieci Tamina marzy już tylko o życiu i nie jest to marzenie ironiczne, choć wysłowione zostaje na chwilę przed śmiercią bohaterki:

Dokąd właściwie chciała wrócić? Do Pragi?

Już nawet o niej nie wiedziała.

Do małego miasta w zachodniej Europie?

Nie. Chciała po prostu odejść.

To znaczy, chciała umrzeć?

Nie, nie, wcale nie. Przeciwnie, strasznie pragnęła żyć.

Ale przecież jakoś musiała sobie wyobrazić świat, w który chciałaby żyć!

W ogóle go sobie nie wyobrażała. Ze wszystkiego pozostało jej tylko wielkie pragnienie życia i własne ciało. Tylko dwie rzeczy, nic więcej. Chciała je zabrać z wyspy i uratować. Swoje ciało i swoje pragnienie życia (KŚZ, 192-193).

Sytuacja Taminy, związanej — podobnie jak Teresa z Nieznośnej lekkości bytu czy Chantal z Tożsamości - z tematem ciała, określona jest wyartykułowanym $\mathrm{w}$ przytoczonym monologu wewnętrznym pragnieniem, któremu na niemożliwej do pokonania przeszkodzie staje nie tyle wiedza, ile klęska wyobraźni implikowana absolutną nieobecnością reguł, jakie mogłyby jej dalszym życiem pokierować. Wolność od egzystencjalnych instrukcji — to porażająca wolność od inspiracji. W przeciwieństwie do Agnes, znajdującej w ojcu mentora przekazującego jej strategię eliptycznego wymazywania się ze świata, Tamina staje przed aporetyczną celowością bez celu, stanowiącą pieśń teraźniejszości, której nie dane jest żadne rozwinięcie. W tej paradoksalnej pieśni streszcza się, jak się wydaje, sens jej powieściowego istnienia. W rozstrzygnięciu losów tej postaci odnaleźć 
można antytetyczną fuzję aktywnej pasywności, o której pisze Jakub Češka, analizując strategię narracyjną Kundery w konteście snu stanowiącego przejaw jednego z ważnych tematów Kafkowskich ${ }^{12}$. Češka kojarzy tematy oniryczne $\mathrm{z}$ niemocą pamięci, w przypadku Taminy mamy jednak do czynienia z niemocą wyobraźni, będącą radykalnym wyzwaniem wobec wyobraźni czytelników. Warto zatem o głos w tej sprawie poprosić jeszcze samego Kunderę, zwłaszcza że w zawartym w Sztuce powieści osobistym słowniku dedykuje temu zjawisku osobną refleksję, ściśle nota bene związaną z przywoływaną wyżej bohaterką:

WYOBRAŹNIA. Pytają mnie: Co chciał pan powiedzieć przez historię Taminy na wyspie dzieci? Ta historia zrodziła się ze snu, który mnie zafascynował; później śniłem go na jawie, a pisząc, rozszerzyłem i pogłębiłem. Jego znaczenie? Proszę bardzo: oniryczny obraz infantokratycznej przyszłości [...]. Ale znaczenie nie poprzedziło snu, to sen poprzedził znaczenie. Należy zatem czytać tę opowieść tak, by pozwolić się ponieść wyobraźni. W żadnym wypadku jako rebus do rozszyfrowania. Kafkolodzy, usiłując rozszyfrować Kafkę, zabili go (SP, 131).

Pragnąc uchylić się od pytania o kierunek, w którym w związku z Taminą wędruje moja własna wyobraźnia, po trosze $\mathrm{z}$ obawy przed zasugerowanym zarzutem symbolicznego zabójstwa grożącego z tego powodu pisarzowi, chciałabym przez chwilę zatrzymać się przy opisywanym przez Kunderę złowrogim fenomenie infantokracji, konsekwentnie postrzeganej w opozycji do skonstruowanej przez encyklopedystów cywilizacji oświecenia. „Powaga dziecka” jest rozumiana tutaj jako diakrytyczna cecha „Wieku Techniki”" ${ }^{3}$, narzucającego nie tyle naiwne, ile bezrefleksyjne partycypowanie w nowoczesności, generującej pogoń za wieczną nowością i intronizującej permanentnie inicjacyjną relację wobec świata. Nie ma w niej miejsca na postój, stanowiący conditio sine qua non dystansu, w którym na prawach ironicznego wycofania się z dynamiki codzienności rozwinąć się może z jednej strony namysł nad owymi kilkoma tematami, z drugiej — zachwyt pozwalający w tej „powolności” pochwycić nic nie znaczące drobiny rzeczywistości, za jakich sprawą manifestuje się teraźniejszość „szczelin istnienia”. Infantokracja likwiduje uważność, w której polu zawiera się refleksyjna reakcja na niewytłumaczalność siebie w równie niewytłumaczalnym świecie, z niej zaś wyłania się scena powieściowej gry w śmiech i zapomnienie, gry w przesłaniającą wszystko ambiwalencję. Wreszcie gry w fundamentalny brak pewności, o jakim pisze przy okazji uwag na temat ironii Kundera ${ }^{14}$. Ów

12 „Fenomén snu můžeme reflektovat $\mathrm{v}$ rozličných paradoxech, přičemž jako jeden z centrálních se ukazuje paradox objektivizované subjektivity či »aktivni« pasivity. Tato vyjádření jsou sice poněkud krkolomná, avšak trefně naznačují onen dvojznačný stav, v němž se jakákoliv aktivita míjí svým cílem, jakékoli snažení vyjde vniveč nebo jím dosáhneme pravého opaku zamýšleného". J. Češka, Průzračnost torby v zrcadle literatury, Praha 2014, s. 99.

${ }^{13}$ Dostarczając wybornego przykładu z Musilowskiego Człowieka bez właściwości, pisarz określa infantokrację (pajdokrację) za pomocą lapidarnej i wymownej frazy: „dzieciństwo jako ideał narzucony ludzkości”. M. Kundera, Sztuka powieści..., s. 113.

14 „Ironia drażni. Nie dlatego, że drwi i napastuje, lecz dlatego, że pozbawia nas pewności, odsłaniając niejednoznaczność świata. [...] Nie ma co utrudniać powieści poprzez stylistyczne 
brak pewności osadza się na języku, który unieważniając własną autonomię, plącze się w zeznaniach odnośnie do rzeczywistości i w efekcie tworzy jej zawsze przekrzywione przedstawienie, oddające naszą niewiedzę w pierwszej kolejności dotyczącą nas samych (fenomen lustra i zmagającej się z nim twarzy). Ta istotowo twórcza deformacja, artystycznie konieczna, poznawczo zaś zawsze nieadekwatna, realizować się może dzięki powolności, której dojrzała postać warunkuje powieściową sztukę retardacji, opowiadaną przez Kunderę za pośrednictwem Point de lendemain (Jutra nie będzie), osiemnastowiecznego opowiadania Vivanta Denona. Sposób skonstruowania sekretnej przygody miłosnej, która w opowiadaniu tym łączy na jedną noc panią de T. z młodym kawalerem, umożliwia oświetlenie diachronicznej dialektyki pamięci oraz zapomnienia, konstytutywnej dla zrozumienia różnicy między uosabianą przez powolność osiemnastowieczną formą a bezkształtem nowoczesnego pośpiechu:

Odcisnąć formę w trwaniu jest wymogiem piękna, lecz także wymogiem pamięci. Albowiem to, co bezkształtne, jest nieuchwytne, nie do zapamiętania. [...]

Istnieje tajemna więź między powolnością a pamięcią, między szybkością a zapomnieniem. [...] stopień powolności jest wprost proporcjonalny do siły pamięci; stopień szybkości jest wprost proporcjonalny do siły zapomnienia ${ }^{15}$.

Antytetycznym biegunem infantokracji byłaby jednak niekoniecznie wykluczona z nowoczesności cywilizacja starości (mimo że w świecie aktualnej Historii, niebędącej historią powieści, ku takiej właśnie zmierzamy), lecz kultura dojrzałości zdolna do twórczych negocjacji z przeszłością, wyposażona w narzędzia umożliwiające $\mathrm{z}$ wiecznego powrotu, o którym w kontekście powieściowego świata Kundery pisze Květoslav Chvatík ${ }^{16}$, uczynić nową wartość. W świecie tym jednak, poza negatywnie nacechowaną ,powagą dziecka”, brak na ogół bezpośredniej tematyzacji wieku, który nie wydaje się dystynktywną właściwością bohaterów. Tym bardziej należy po raz kolejny siegnąć do Sztuki powieści, by z jej sumplementarnego leksykonu wywieść ten oto cytat:

zabiegi; każda powieść godna tej nazwy, nawet najbardziej przejrzysta, jest wystarczająco trudna z uwagi na ironię, należącą do jej istoty". Ibidem.

${ }^{15}$ M. Kundera, Powolność, przeł. M. Bieńczyk, Warszawa 2015, s. 34-35.

16 W nawiązaniu do Niewiedzy operującej archetypem powrotu Odyseusza do Itaki badacz zestawia Nietzscheańską ideę z rozrywającym tożsamość doświadczeniem emigracji: „Emigrace s sebou přináší stavy schizofrenie, které se projevují zejména v emigrantských snech. Člověk se ve snu ocitá na známých místech domowa a současně zakouší smrtelnou úzkost, že z těchto kdysi milovaných míst pro něho není úniku, že skončí ve spárech nepřátelské policie. Schizofrenie emigrace: část vědomí žije ve vzpomínkách na mládí, na první lásku, na první pechy a nezdary a šálivá pamĕt' vybírá podle vlastní režie jen světlé okamžiky; druhá část vědomí se plně koncentruje na přitomnost, na nové úkoly, akceptuje požadavky nového prostředí. Není pochyb o tom, že podobný stav může vybičovat k větší výkonnosti, než k jaké vedla nehybnost, nuda a čas zapomnění v okupovaných Čechach doby normalizace. Konfrontace s novým prostorem přináší nové zážitky a nové žvotní zkušenosti, učí pruneli reagovat na nové úkoly”. K. Chvatík, Svět románů Milana Kundery, Brno 2008, s. 142. 
STAROŚĆ. „Stary profesor obserwował hałaśliwych młodzieńców i nagle zrozumiał, że on jeden w tej sali posiadł przywilej wolności, ponieważ był stary; dopiero na starość człowiek może nie zważać na opinię stada, na opinię publiczności i przyszłości. Jest sam na sam z bliską już śmiercią, a śmierć nie ma oczu ani uszu i człowiek nie musi się jej podobać; może robić i mówić to, co podoba się jemu" (Życie jest gdzie indziej). Rembrandt i Picasso. Bruckner i Janaczek. Bach ze Sztuki fugi (SP, 129).

Przywołany passus stanowi od strony formalno-stylistycznej strukturę drugiego stopnia, potwierdzającą autotematyczną skłonność pisarza do swobodnego cytowania własnych powieści, zabezpieczonego jednakowoż ironicznym cydzysłowem, niemniej na poziomie narracyjnym zdradza subtelną korespondencję odnoszącą się do opowiadania Brunona Schulza zatytułowanego Emeryt. W ostatnich frazach owej pierwszoosobowej narracji bohater rezygnuje $\mathrm{z}$ wtłaczającego go w pubertalne porządki życia i pozwala, niczym Kafkowski Grakhus, unieść się żywiołowi. Porwany przez fantastyczny powietrzny wir, odpowiednik rydwanu uwożącego w przestworza biblijnego Eliasza, bohater roztapia się na horyzoncie w żółtym świetle jesieni, preludium do ostatecznej wolności, oznaczającej rozbrat ze światem, w którym „pochyleni ku ziemi wszyscy dążą dokądś, wymijają się niecierpliwie i ulica porysowana jest cała liniami tych dążeń, spotkań i wymijań" ${ }^{17}$. Intronizacja wolności, do której w przedziwny sposób zaprasza starość, oznacza u Schulza doświadzczanie stanów niezwykle bliskich Kunderowskiemu światoodczuciu; należą do nich brak patosu, banalność, taneczna lekkość, pustka, niezależność, nieodpowiedzialność, zniwelowanie różnic, rozluźnienie wszelkich więzów, rozprzęgnięcie się granic, bezdenność, wszędobylskość. „Nic mnie nie trzyma i nic nie więzi — dodaje Schulzowski narrator — brak oporu, bezgraniczna swoboda"18. Wszystkie te właściwości mogłyby ułożyć się w łańcuch niewiele znaczących enumeracji, gdyby nie antyteza wewnętrznego ciężaru, którego nie sposób już wyartykułować: jego świadomość niesie się na barkach z uporem sędziwego Beethovena szlifującego pod koniec życia pozornie banalne wariacje, o jakich w autobiograficznym wątku Księgi śmiechu i zapomnienia pisze Kundera $^{19}$.

W słynnej debacie, toczonej na kartach Nieśmiertelności przez Goethego i Hemingwaya, jedną z najważniejszych stawek okazuje się trud, który wiąże się z konstruowaniem obwieszczanemu światu ,ja”, wynikający z „niepoprawnej niedojrzałości człowieka. Jakże trudno - kontynuuje Goethe - zachować obojętność wobec własnego wizerunku! Taka obojętność jest ponad ludzkie siły.

${ }^{17}$ B. Schulz, Sklepy cynamonowe. Sanatorium pod klepsydra, Warszawa 1994, s. 297-298.

18 Ibidem, s. 295.

19 „Beethoven pod koniec życia szczególnie upodobał sobie formę wariacji. Na pierwszy rzut oka mogłoby się wydawać, że ze wszystkich form ta właśnie jest najbardziej płytka; zwykła prezentacja techniki muzycznej, praca odpowiednia dla amatora, a nie dla Beethovena. Tymczasem on po raz pierwszy w historii muzyki uczynił z niej jedną z najwspanialszych form, w której zawarł swe najgłębsze przemyślenia”. M. Kundera, Księga śmiechu i zapomnienia, przeł. P. Godlewski, A. Jagodziński, Warszawa 1993, s. 165. 
Człowiek osiąga ją dopiero po śmierci. I też nie od razu"20. Niedojrzałość jawi się pozornie stanem odwrotnie proporcjonalnym wobec zapomnienia, jako że troska o nieśmiertelność uparcie wypiera trudną, często nawet niemożliwą myśl o własnym nie-byciu. Kwintesencją nieobecności jest jednak śmiertelność, której zdarzenie odpowiada za spustoszenie pamięci tego, kto pozostaje jeszcze przy życiu. W zmaganiach $\mathrm{z}$ restytucją mentalnego obrazu zmarłego, opowiadaną z perspektywy Taminy, wkracza się w pułapkę zapominania, w której „,rzeczywistym" przedmiotem podszytej melancholią żałoby staje się właśnie nieobecność. Kundera podkreśla zatem, że „Wspomnienie nie jest zaprzeczeniem zapomnienia. Wspomnienie jest formą zapomnienia" ${ }^{21}$ fundującego nieobecność. To z jej powodu się cierpi, to ona nakłuwa - niczym punctum z fotograficznej kolekcji Rolanda Barthes'a ${ }^{22}$ — i pozostawia w stanie niemego wstrząsu, który nie ustępuje do końca. Starość - to suma nakłuć, którą neutralizuje bliskość własnej śmierci. Ale w chwili wolności może spłynąć także łaska picassowskiej radości, doświadczenie bycia w elipsie, pauzie odciążanej z balastu egzystencji na czasowość skazanej. I na lekceważenie ze strony Historii.

Innym wykładnikiem literackiej starości, wiecznego i par excellence ironicznego powrotu nowego, jest skłonność do palinodii, która w pełnej zgodzie ze strukturalną dominantą tego antycznego gatunku oznacza odwołanie uprzednio wyznawanych sądów na rzecz wysłowienia nowego światopoglądu. W literaturze spod znaku Kundery postawa ta inauguruje kolejny rodzaj walki wypowiadanej przeciwko „myśli zastygłej”, przeciwko martwemu przekonaniu stanowiącemu negację ruchu zawiadującego performatywną inspiracją. Na antypodach dewastującego ów ruch przekonania znajduje się „myśl eksperymentalna”, definiowana w ten sposób przez Hannah Arendt w odniesieniu do filozofii Nietzschego, u Kundery zaś zderzona ze strategią nicestwienia systemowych ograniczeń (ZT, 157-159) ${ }^{23}$. Strategia ta, nawiasem mówiąc, w pełni przylega do postrzegania literatury jako „siły zdarzeniowości” warunkującej autotransgresję, która z kolei gwarantuje ,poszerzenie tematyczne" 24 . Z perspektywy takiego Nietzscheań-

${ }^{20}$ M. Kundera, Nieśmiertelność, przeł. M. Bieńczyk, Warszawa 1995, s. 207.

${ }^{21}$ M. Kundera, Zdradzone testamenty..., s. 116.

22 „To słowo [punctum - A.M.S.] odpowiadałoby mi tym bardziej, że odsyła także do znaku kropki, a zdjęcia, o których mówię, są rzeczywiście jakby zaznaczone punktami, czasami nawet usiane tymi wrażliwymi miejscami. [...] punctum to także użądlenie, dziurka, plamka, małe przecięcie - ale również rzut kośćmi. Punctum jakiegoś zdjęcia to przypadek, który w tym zdjęciu celuje we mnie [me point] (ale też uderza mnie, miażdży)" — R. Barthes, Światto obrazu. Uwagi o fotografii, przeł. J. Trznadel, Warszawa 2008, s. 51-51.

${ }_{23}$ M. Kundera, Zdradzone testamenty..., s. 157-159.

24 „Siła zdarzeniowości”, wywiedziona przez Derridę z performatywności literatury, oznacza jej najbardziej ejdetyczną cechę czy właściwość, która sprowadza się do nieprzewidywalnych efektów jej zdarzeń, rzutujących na fuzję dwóch doświadczeń czy horyzontów: piszącego oraz czytającego: „Czytanie wiąże się z przekształcaniem”. J. Derrida, Pozycje. Rozmowy z Henri Ronsem, Julia Kristeva, Jean-Louisem Houdebinem i Guy Scarpetta, przeł. A. Dziadek, Bytom 1997, s. 60 . 
skiego poszerzenia żywioł powieściowy demontuje linie demarkacyjne oddzielające go od innych dyscyplin, wkracza do filozofii, sztuk plastycznych bądź muzyki, staje się w sposób „świadomy” intersemiotyczny, wielojęzyczny. Palinodia okazuje się mniej bądź bardziej dyskretną sojuszniczką zmiany, którą żywi się autotransgresja, ugruntowana na pracy i ekonomii różnicy. Rzuca przy tym nowe, ponownie pozytywne światło na starość, w tym wypadku oznajmującą pragnienie transformacji, gdyż, paradoksalnie, pod jej nieobecność nie zrodziłoby się owo pragnienie. Przekroczenie starości w kierunku nowości, ilustrowane genologicznym chwytem palinodii lub po prostu parodią, żywi się przecież przeszłością i na mocy sekretnej kontradykcji stale ku niej się zwraca: nawet jeśli w owym zwrocie kompromituje czy podcina przebrzmiałe wartości, to jednocześnie w trybie apofatycznym bądź negatywnym bez końca je przywołuje. Oto sens owego przekroczenia, potwierdzony tautologicznym pragnieniem nieskończonej zmiany sensu, w skrajnych przypadkach zaś — jego odwołaniem. Chociaż nieobecna expressis verbis w idiomie Kundery, palinodia bynajmniej nie jest mu obca. Dostrzec ją można najlepiej w geście odwołania czeskiej tożsamości językowej na rzecz francuskiej, geście, który sprawia nadejście atopii oznajmującej, mówiąc słowami Lacana, utratę bezpiecznej iluzji ,ja”. Atopia jest zatem świadomą zgodą na wygnanie, na wolność od tożsamościowego mitu, zbieżną z doświadczeniem starości, która rezygnuje z upartego poszukiwania własnego obrazu. W poruszającym Dzienniku żałobnym Barthes’a napotykam serię zdjęć dokumentujących dzieciństwo pisarza. Pod jednym z nich umieszczone są takie oto słowa:

You are the only one who can never see yourself except as an image: you never see your eyes unless they are dulled by the gaze they rest upon the mirror or the lens (I am interested in seeing my eyes only when they look at you): even and especially for your own body, you are condemned to the repertoire of its images.

[...] My body is free of its image-repertoire only when it establishes its work space. This space is the same everywhere, patiently adapted to the pleasure of painting, writing, sorting ${ }^{25}$.

Cytuję to bliskie konfesji rozpoznanie, ponieważ doskonale przylega do twierdzenia Kundery dotyczącego istotowej nieprawdy doświadczanej w trakcie obcowania z własnym obrazem, boleśnie rozbieżnym od tych wszystkich obrazów nas samych w oczach innych. W konsekwencji ,nigdy nie dowiadujemy się, dlaczego i czym drażnimy innych, co w nas wydaje im się sympatyczne, a co śmieszne; nasz własny obraz jest dla nas największą tajemnicą"26. Starość — to czas, w którym tracimy niepokój z powodu tajemnicy naszego własnego obrazu; tajemnica, być może, żyje w nas nadal (uwolniona od obrazu), ale w niezwykły sposób przestaje nas ona obchodzić. Jest co najwyżej, podobnie jak śmiertelność, źródłem nieostentacyjnego znużenia. Nuży bowiem celowość, wzięta w nawias ujawnia magię przypadku, za sprawą której dostrzec można efemeryczną urodę

${ }^{25}$ R. Barthes, Mourning Diary, przeł. R. Howard, New York 2010, s. 39-41.

${ }^{26}$ M. Kundera, Nieśmiertelność..., s. 124. 
świata postrzegano w pomniejszeniu, w detalu. Za sprawą tej wyizolowanej z retoryki litoty, która niczym akomodujący mechanizm przesterowuje widzenie na powolną uważność, świat zbliża się do snu, który Češka trafnie kojarzy z „dobrowolnym opuszczeniem trajektorii ludzkiej egzystencji”27. Przywilejem starości, podpowiada dyskretnie powieść spod znaku Kundery, jest dojrzewanie do litoty odsłaniającej bycie, podczas gdy ,,życie jest gdzie indziej”.

W dyskretnej apologii podszytej litotą starości zawiera się wreszcie afirmacja nieistotności tytułowej bohaterki ostatniej powieści Kundery, której przewrotnym i paradoksalnym tryumfem nad skandalicznie śmiercionośnym czasem jest utrata prawdziwie ulotnych dystynkcji, śmiesznych i śmieszących w obliczu repetycji streszczających się w figurze pępka ${ }^{28}$. Niemożliwa do pomyślenia jednostkowość owej figury, ubarwiona może jedynie Freudowskim fantazmatem ${ }^{29}$, znika pod naporem czystego powtórzenia, które warunkuje fenomen przezroczystości ${ }^{30}$, w wymiarze egzystencjalnym oznaczający trwanie dla nikogo, całkowitą niewidoczność, antycypowaną uprzednią obecnością, doświadczaną przez Chantal z Tożsamości. Ostateczną konsekwencją litoty może być wszak redukcja tematu, eliminacja problemu, porzucenie niezręcznego motywu... Z ową konsekwencją boryka się również u Kundery starość świadoma kruchości granicy oddzielającej nieistotność od nieobecności.

\section{Bibliografia}

Ashbery J., Inne tradycje, przeł. J. Fiedorczuk et al., przedmowa G. Jankowicz, Korporacja ha!art, Kraków 2008.

Barthes R., Mourning Diary, przeł. R. Howard, Hill \& Wang, New York 2010.

Barthes R., Światło obrazu. Uwagi o fotografii, przeł. J. Trznadel, Wydawnictwo Aletheia, Warszawa 2008.

Bieńczyk M., Książka twarzy, Świat Książki, Warszawa 2012.

Bieńczyk M., Przezroczystość, Wielka Litera, Warszawa 2015.

27 J. Češka, op. cit., s. 66.

28 „Miłość była niegdyś świętem jednostkowości, niepowtarzalności, pochwałą tego, co jest wyjątkowe, co nie zniesie żadnego powtórzenia. Ale pępek nie dość, że nie buntuje się przeciw powtórzeniu, to jeszcze wzywa do powtórzenia! I nasze nowe tysiąclecie będziemy przeżywać pod znakiem pępka”. M. Kundera, Święto nieistotności, przeł. M. Bieńczyk, Warszawa 2015, s. 103.

${ }^{29}$ Nawiązuję tutaj, rzecz jasna, do somatycznej metafory pępka snu, potwierdzającej poniekąd klęskę Freuda poniesioną na polu analizy marzeń sennych, analizy mającej wieść ku sferze podświadomości, której manifestację uznać jednak należy za niemożliwą: „Nawet w wypadku doskonale objaśnionych marzeń sennych często trzeba zostawić jakieś mroczne miejsce [...], ponieważ w trakcie wykładania zauważa się, że bierze tam początek kłąb myśli [...], który opiera się rozwikłaniu, który jednak nie wniósł też żadnego dalszego wkładu do treści sennej. Jest to pępek snu [...], w którym dotyka on tego, co nieznane". Z. Freud, Objaśnianie marzeń sennych, [w:] idem, Dzieła, t. I, przeł. R. Reszke, Warszawa 1996, s. 443.

${ }^{30} \mathrm{O}$ roztapianiu się w przezroczystości, owym trwaniu dla nikogo pisze M. Bieńczyk w: Przezroczystość, Warszawa 2015, s. 326-327. 
Bloom H., Lęk przed wptywem. Teoria poezji, przeł. A. Bielik-Robson, M. Szuster, TAiWPN UNIVERSITAS, Kraków 2002.

Bloom H., The Western Canon. The Books and School of the Ages, Riverhead Books, New York 1995.

Češka J., Průzračnost tvorby v zrcadle literatury, Togga, Praha 2014.

Chvatík K., Svět románů Milana Kundery, Atlantis, Brno 2008.

Derrida J., Pozycje. Rozmowy z Henri Ronsem, Julia Kristeva, Jean-Louisem Houdebinem i Guy Scarpetta, przeł. A. Dziadek, Wydawnictwo FA-art, Bytom 1997.

Derrida J., Ta dziwna instytucja zwana literatura. Z Jacques'em Derrida rozmawia Derek Attridge, przeł. M.P. Markowski, „Literatura na Świecie” 1998, nr 11-12.

Freud Z., Objaśnianie marzeń sennych, [w:] idem, Dzieła, t. I, przeł. R. Reszke, Wydawnictwo KR, Warszawa 1986.

Kundera M., Księga śmiechu i zapomnienia, przeł. P. Godlewski, A. Jagodziński, Państwowy Instytut Wydawniczy, Warszawa 1993.

Kundera M., Nieśmiertelność, przeł. M. Bieńczyk, Państwowy Instytut Wydawniczy, Warszawa 1995.

Kundera M., Niewiedza, przeł. M. Bieńczyk, Wydawnictwo WAB, Warszawa 2015.

Kundera M., Powolność, przeł. M. Bieńczyk, Wydawnictwo WAB, Warszawa 2015.

Kundera M., Sztuka powieści. Esej, wyd. drugie zmienione, przeł. M. Bińczyk, Państwowy Instytut Wydawniczy, Warszawa 2004.

Kundera M., Święto nieistotności, przeł. M. Bieńczyk, Wydawnictwo WAB, Warszawa 2015.

Kundera M., Tożsamość, przeł. M. Bieńczyk, Wydawnictwo WAB, Warszawa 2015.

Kundera M., Zdradzone testamenty. Esej, przeł. M. Bieńczyk, Państwowy Instytut Wydawniczy, Warszawa 1996.

Ricard F., Agnés's Final Afternoon. An essay on the work of Milan Kundera, przeł. A. Asher, Faber and Faber, London 2003.

Schulz B., Sklepy cynamonowe. Sanatorium pod klepsydra, Państwowy Instytut Wydawniczy, Warszawa 1994.

\section{A discreet apology of old age in the works of Milan Kundera}

\section{Summary}

In the essay, the titular problem of old age is related to the great literary canon, within which the history of novel is established and developed. The canon itself, in terms of H. Bloom, means a perpetual and creative source of struggle against the literary traditions' influence, which is also to shape Kundera's novels and essays. Thus the old age is conceived as a broad metaphor consisting of the great works of the great precursors, who invented us along with our modern world. Furthermore, Kundera allows his readers to associate the old age motif with a wide range of often opposite properties alike slowness, carefulness, lightness, triviality, laughter, transparence, non-presence, or non-essence, etc. These properties are rendered by a series of the writer's favorite figures, to which belong: irony, ellipsis, and litotes that are to determine the central motif of vis comica inherited by Kundera from his masters, Cervantes, Rabelais, Diderot, and Sterne.

Keywords: literary canon, influence, parody, palinode, litotes 


\section{Diskrétní apologie stáří v díle Milana Kundery}

Obsah

V článku je problematika stáří konfrontována s evropským literárním kánonem, který obsahuje a vytváří dějiny evropského románu. Tento kánon, v souladu s teorií Harolda Blooma, tvoří nekonečný tvůrčí zdroj boje s literární tradicí, boje, který se rovněž zrcadlí v románech Milana Kundery. V jeho díle je stáŕí zobrazeno jako široce chápaná metafora děl velkých spisovatelů, kteří jsou zodpovědni za obraz současného světa. Kundera pracuje s motivem stáří a srovnává ho s celou škálou témat, která ho zajímají, tzn. s retardací, opatrností, lehkostí, triviálností, humorem, průhledností, nepřítomostí, bezvýznamností apod. K zobrazení těchto témat využivá své oblíbené figury: ironii, elipsu a litotésu, které determinují problematiku vis comica, přejatou od oblíbených předchůdců. Jsou mezi nimi Cervantes, Rabelais, Diderot a Sterne.

Klíčová slova: literární kánon, literární agón, vliv, parodie, palinodie 